\title{
Clinical parameters of inflammatory bowel disease in children do not correlate with four common polymorphisms of the transforming growth factor $\beta 1$ gene
}

\author{
Anna Liberek1', Joanna Jakóbkiewicz-Banecka², Anna Kloska², Joanna Świderska², Zbigniew \\ Kmieć ${ }^{3}$, Grażyna Łuczak¹, Piotr Wierzbicki³, Tomasz Liberek', Krzysztof Marek¹, Katarzyna Pla- \\ ta-Nazar1, Grażyna Sikorska-Wiśniewska', Barbara Kamińska and Grzegorz Węgrzyn²
}

'Department of Pediatrics, Pediatric Gastroenterology, Hepatology and Nutrition, Medical University of Gdańsk, Gdańsk, Poland; 2Department of Molecular Biology, University of Gdańsk, Gdańsk, Poland; ${ }^{3}$ Department of Histology, Medical University of Gdańsk, Gdańsk, Poland; ${ }^{4}$ Department of Nephrology, Transplantology and Internal Medicine, Medical University of Gdańsk, Gdańsk, Poland

Transforming growth factor $\beta 1$ (TGF- $\beta 1$ ) is a cytokine affecting cell proliferation and development, which also has an immunomodulatory activity. Correlations between polymorphisms of the TGF- $\beta 1$ gene and clinical parameters of inflammatory bowel disease (IBD) were reported previously in adults. Here, we tested whether such correlations occur in pediatric patients suffering from IBD. One hundred and four pediatric IBD patients were involved in this study. Among them, 36 were diagnosed with Crohn's Disease (CD) and 68 were diagnosed with ulcerative colitis (UC). The control group consisted of 103 children, in which IBD was excluded. TGF- $\beta 1$ levels were determined in plasma and intestinal mucosa samples. The presence of the TGF $\beta 1$ protein and the amount of TGF $\beta 1$ mRNA were estimated in intestinal mucosa by immunohistochemistry and reverse transcription Real-Time PCR, respectively. Four common polymorphisms of the TGF- $\beta 1$ gene were investigated: $-800 \mathrm{G} / \mathrm{A}$, $-509 \mathrm{C} / \mathrm{T}, 869 \mathrm{~T} / \mathrm{C}$ and $915 \mathrm{G} / \mathrm{C}$. No significant correlation between TGF- $\beta 1$ genotypes and (i) TGF- $\beta 1$ levels in plasma and tissue samples, (ii) TGF- $\beta 1$ gene expression efficiency in intestinal mucosa, (iii) IBD clinical parameters and (iv) inflammatory activity could be detected in children suffering from IBD. We conclude that, contrary to previous suggestions, the four common polymorphisms of the TGF- $\beta 1$ gene do not influence the susceptibility to or clinical parameters of IBD in the tested population of children.

Keywords: Transforming growth factor $\beta 1$, gene polymorphism, inflammatory bowel disease, pediatric patients

Received: 14 November, 2011; revised: 30 November, 2011 ; accepted: 01 December, 2011; available on-line: 03 December, 2011

\section{INTRODUCTION}

Transforming growth factor $\beta 1$ (TGF- $\beta 1$ ) is a cytokine exhibiting a broad range of activities. It is involved in the control of cell differentiation and proliferation, activation of immune cells, wound healing and angiogenesis. Correlations between polymorphisms of the TGF- $\beta 1$ gene and either susceptibility to various diseases or their clinical parameters were reported (Cotton et al., 2002; Gewaltig et al., 2002; Vidigal et al., 2002; Park et al., 2003; Coll et al., 2004; Yang et al., 2004; Drumm et al., 2005; Cantor et al. 2005; Mak et al., 2006). It appears that TGF- $\beta 1$ plays an important role in inflammatory bowel disease (IBD) as significant increases in both efficiency of TGF- $\beta 1$ gene transcription and levels of the TGF- $\beta 1$ protein have been reported in patients suffering from Crohn's disease (CD) and ulcerative colitis (UC) (Powrie et al., 1996; Fiocchi, 1998). It was postulated that the TT genotype at the -509 position of the TGF- $\beta 1$ locus was associated with the stricture forming type of the CD (Schulte et al., 2001), and this type of the disease was also associated with a particular genotype at the 915 position (G/C polymorphism) (Hume et al., 2006). Moreover, significant differences in allele frequencies and genotypes at the -800 position ( $\mathrm{G} / \mathrm{A}$ polymorphism) of the TGF- $\beta 1$ locus were found between patients with UC and control subjects (Tamizifar et al., 2008). However, to our knowledge, all studies on the role of TGF- $\beta 1$ polymorphisms in IBD reported to date were performed in adult patients. Therefore, we have investigated whether these polymorphisms may play a role in IBD in children.

Eight common polymorphisms of the TGF- $\beta 1$ gene have been described to date (Derynck et al., 1987; Cambien et al., 1996; Langdahl et al., 1997; Syrris et al., 1998; Grainger et al., 1999). Among them, the following four are the most frequent: $-800 \mathrm{G} / \mathrm{A}$ and $-509 \mathrm{C} / \mathrm{T}$ in the promoter region, and $869 \mathrm{~T} / \mathrm{C}$ and $915 \mathrm{G} / \mathrm{C}$ in exon 1 , as shown in Fig 1 (Bayat et al., 2002; Kim et al., 2003; Suzuki et al., 2003; Lee-Chen et al., 2004; Osterreicher et al., $2005)$. Because of this, and due to the fact that some effects of TGF- $\beta 1$ polymorphism on IBD was reported to date only for $-800 \mathrm{G} / \mathrm{A},-509 \mathrm{C} / \mathrm{T}$ and $915 \mathrm{G} / \mathrm{C}$ (Schulte et al., 2001; Hume et al., 2006; Tamizifar et al., 2008), in our studies we have tested these four polymorphisms.

\section{MATERIALS AND METHODS}

Patients. One hundred and four pediatric IBD patients (36 diagnosed for CD and 68 diagnosed for UC), were tested. This group consisted of 67 males and 37 females, at the age between 1.5 and 18.5 years (mean: $13.0 \pm 4.5 \mathrm{y}$, median: $14.5 \mathrm{y}$ ).

One hundred and three children represented the control group, which consisted of 65 males and 38 females, 2.0-18.0 years old (mean $11.0 \pm 5.0$, median 11.0), who underwent endoscopy, because of gastrointestinal bleed-

e-mail: wegrzyn@biotech.univ.gda.p

Abbreviations: CD, Crohn's Disease; IBD, inflammatory bowel disease; TGF- $\beta 1$, transforming growth factor $\beta 1$; UC, ulcerative colitis. 
ing events; in this group of patients inflammatory processes, immune disorders, malignancies and nutritional abnormalities were excluded. None of the patients received immunomodulating therapy at least 6 months prior to the study.

Endoscopic and histological classifications of intestinal mucosa were performed according to the Porto criteria (IBD Working Group of the European Society for Paediatric Gastroenterology, Hepatology and Nutrition, 2005). Among IBD patients, severities of CD and UC were estimated according to the Hyams scale (Pediatric Crohn's Disease Activity Index, PCDAI) and the Truelove-Witts scale, respectively (Hyams et al., 1991; Truelove and Witts, 1954).

Following parameters were determined for all subjects: full blood count, erythrocyte sedimentation rate (ESR), serum total protein, C-reactive protein (CRP), and iron.

Determination of TGF- $\beta 1$ plasma concentration. Concentration of the TGF- $\beta 1$ protein in plasma was determined by sandwich ELISA method (Quantikine kit, R\&D Systems, Minneapolis, MN, USA), according to the manufacturer's instructions.

Detection of TGF- $\beta 1$ in intestinal mucosa. TGF- $\beta 1$ was detected in samples of intestinal mucosa by immunohistochemical methods, using Vactastain ABC Kit PK-4001 (Vector Laboratories, Burlingame, CA, USA).

Estimation of the level of mRNA of the TGF- $\beta 1$ gene. The mRNA level in the intestinal mucosa was estimated by the two-step reverse transcription quantitative real-time PCR method. Total RNA was isolated with Total RNA Prep Plus kit (A\&A Biotechnology, Gdynia, Poland) and stored at $-80^{\circ} \mathrm{C}$. Quality and concentration of RNA was determined spectrophotometrically, using Smart Spec 3000 apparatus (Bio-Rad Lab., Herts, UK). $1 \mu \mathrm{g}$ of RNA, $0.25 \mu \mathrm{g}$ of oligo $\mathrm{T}_{18}$ and M-MLV enzyme (Promega, Madison, WI, USA) were used for reverse transcription in a total volume of $10 \mu \mathrm{l}$. Quantitative real-time PCR reaction mixture contained $0.4 \mu \mathrm{l} \mathrm{cDNA}$, $180 \mathrm{nM}$ each primer and iQSybrGreen Supermix kit (Bio$\mathrm{Rad}$ ), and the reaction was performed in iCycler iQ (Bio$\mathrm{Rad})$ in a total volume of $20 \mu \mathrm{l}$. Primers for TGF- $\beta 1$ and $A C T B$ were designed using Primer3Plus, based on BLAST, ENSMBL and AceView databases; TGF-31: 5'-CAG CAA CAA TTC CTG GCG ATA CC and TGFß-2, 5'-CGA AAG CCC TCA AT'T TCC CCT C, bact1-1, 5'-TGT GCC CAT CTA CGA GGG GTA TGC and bact1-2, 5'-GGT ACA TGG TGG TGC CGC CAG ACA. The following primers were used in the reaction: TGF- $\beta 1,5^{\prime}-\mathrm{CAG}$ CAA CAA TTC CTG GCG ATA CC and TGFß-2, 5'CGA AAG CCC TCA ATT TCC CCT C. The reactions were run in triplicate and the obtained data were averaged followed by data analysis calculated with iQ ver. 3.1 software (Bio-Rad). It was previously demonstrated that $A C T B$ showed constant expression in IBD (Stanislawowski et al., 2009; Wierzbicki et al., 2009), thus, this gene was used to normalize the values in the common $\Delta \Delta$ Ct quantification method.

Genotyping. The following polymorphisms of the TGF- $\beta 1$ gene were determined: $-800 \mathrm{G} / \mathrm{A}, 509 \mathrm{C} / \mathrm{T}$, $869 \mathrm{~T} / \mathrm{C}$ and $915 \mathrm{G} / \mathrm{C}$. DNA was isolated from blood samples by using QIAamp DNA Blood Mini Kit (QIAGEN, Germany). Appropriate regions of the TGF- $\beta 1$ locus were amplified by PCR using the following primers: TGF1 (5'-T'TC CCT CGA GGC CCT CCT A) and TGF2 (5'-GCC GCA GCT TGG ACA GGA TC) for the exon 1 fragment, and TGF3 (5'-GGG GAC ACC ATC TAC AGT G) and TGF4 (5'-GGA GGA GGG GGC AAC AGG) for the promoter region. The ampli- fied DNA fragments were treated with MaeIII, Eco81I, MspA1I or $B g / I$ restriction enzymes to determine specific polymorphisms, $-800 \mathrm{G} / \mathrm{A},-509 \mathrm{C} / \mathrm{T}, 869 \mathrm{~T} / \mathrm{C}$ or $915 \mathrm{G} / \mathrm{C}$, respectively. Restriction fragments were separated electrophoretically and particular genotypes were determined on the basis of patterns of bands in the gel.

Statistical analysis. Statistical analysis of the results was performed using non-parametric tests: the Mann-Whitney test for comparison of two groups, the ANOVA Kruskal-Wallis test for comparison of several groups, and the Spearman correlation test. For qualitative parameters, the Paerson's $\chi^{2}$ test was used, with Yates correction if $\mathrm{n}<10$. The results were considered statistically significant when $p<0.05$. The calculations were performed with the use of Statistica 7 software (StatSoft Inc., Tulsa, OK, USA).

Ethical considerations. This study was approved by the Independent Bio-Ethical Committee for Research at the Medical University of Gdańsk (NKEBN/13/2004). Informed consents of the patients' parents or legal guardians were obtained prior to the study.

\section{RESULTS}

The frequencies of particular genotypes at four polymorphic sites (-800G/A, -509C/T, 869T/C and

Table 1. Frequencies of particular genotypes at four polymorphic sites $(-800 \mathrm{G} / \mathrm{A},-509 \mathrm{C} / \mathrm{T}, 869 \mathrm{~T} / \mathrm{C}$ and $915 \mathrm{G} / \mathrm{C})$ of the TGF- $\beta 1$ locus in the IBD group and control.

Statistically significant difference is marked by an asterisk.

\begin{tabular}{llc}
\hline \multirow{2}{*}{ TGF $\beta 1$ polymorphism } & \multicolumn{2}{l}{ Number of cases (frequency in \%) } \\
\cline { 2 - 3 } & IBD & control \\
\hline C-509T & $34(40.5 \%)$ & $37(35.9 \%)$ \\
CC & $30(35.7 \%)$ & $50(48.5 \%) *$ \\
CT & $20(23.8 \%)$ & $16(15.5 \%)$ \\
TT & 84 & 103
\end{tabular}

$\begin{array}{lll}\text { T869C } & \\ \text { TT } & 23(27.4 \%) & 32(31.1 \%) \\ \text { TC } & 41(48.8 \%) & 46(44.7 \%) \\ \text { CC } & 20(23.8 \%) & 25(24.3 \%) \\ \text { Total number of cases } & 84 & 103\end{array}$

$\begin{array}{lll}\text { G915C } & & \\ \text { GG } & 72(85.7 \%) & 90(87.4 \%) \\ \text { CG } & 12(14.3 \%) & 12(11.7 \%) \\ \text { CC } & 0(0 \%) & 1(1.0 \%) \\ \text { Total number of cases } & 84 & 103\end{array}$

\begin{tabular}{lll} 
G-800A & \\
GG & $76(90.5 \%)$ & $93(90.3 \%)$ \\
GA & $7(8.3 \%)$ & $10(9.7 \%)$ \\
AA & $1(1.2 \%)$ & $0(0 \%)$ \\
Total number of cases & 84 & 103 \\
\hline
\end{tabular}


41.89 MBp

F

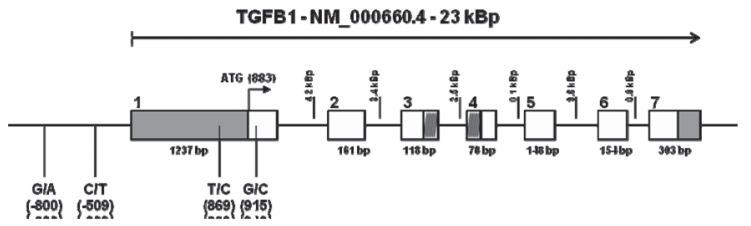

Figure 1. Schematic view of the genetic organization of TGFB1. The structure of the TGFB1 gene region (with accession number) shows 7 exons (boxes) with sizes indicated below boxes. Sizes of introns are represented by vertical numbers. The scheme is shown not to scale. Grey areas mark 5'UTR and 3'UTR, respectively. Hatched boxes represent location of the exons considered in reverse transcriptase real-time PCR assay for TGFB1 mRNA quantification. Location of specific sites are shown in brackets. The polymophic sites analyzed in this study are shown below the transcription outline.

915G/C) of the TGF- $\beta 1$ locus in pediatric patients suffering from IBD and in control subjects are presented in Table 1 . There were no statistically significant differences in the frequencies of particular genotypes between tested groups, but one exception, namely, a higher number of -509 CT heterozygotes was found in the control group relative to IBD patients $(p=0.04)$. Moreover, no significant differences were observed between control and CD and UC patients as well as between UC and CD patients (not shown).

No statistically significant differences among IBD patients, and within UC and CD subgroups, were found in relation to the clinical parameters of the disease, the immunohistochemically determined tissue content of TGF- $\beta 1$, the levels of TGF- $\beta 1$ in plasma, and levels of mRNA of the TGF- $\beta 1$ gene in intestinal mucosa samples (Table 1 and not shown). Moreover, there were no significant differences between TGF- $\beta 1$ polymorphisms and selected cytological and biochemical parameters (WBC, ESR, iron concentration and total protein concentration) measured in blood samples of IBD patients. The only two statistically significant differences were found when the $-509 \mathrm{C} / \mathrm{T}$ polymorphism was tested in relation to platelet count and CRP level. The platelet count was significantly higher in T'T homozygotes than in CC homozygotes and heterozygotes $(p=0.04$ ) (Fig. 2), and a significantly increased CRP level was found in -509CC homozygotes, relative to CT and TT genotypes $(p=0.01)$ (Fig. 3) in the study group.

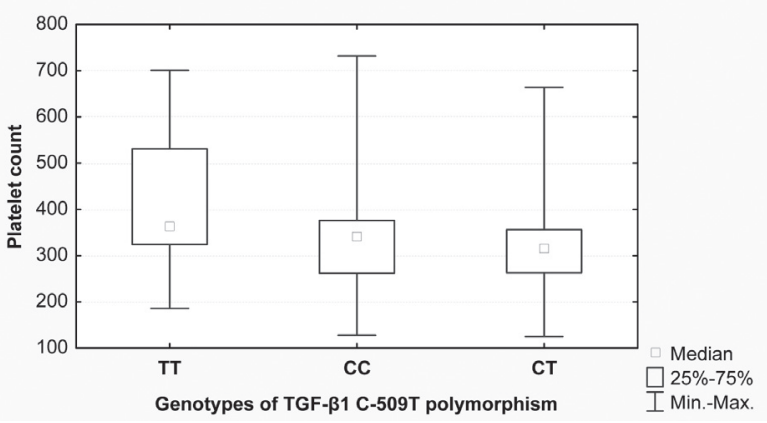

Figure 2. Platelet count in relation to genotypes of TGF- $\beta 1$ C$509 \mathrm{~T}$ polymorphism in the study group.

\section{DISCUSSION}

Previous reports by other authors suggested a role for TGF- $\beta 1$ polymorphism in the clinical parameters of IBD. Particularly, $-509 \mathrm{C} / \mathrm{T}$ and $915 \mathrm{G} / \mathrm{C}$ polymorphisms were reported to be associated with different frequencies of the stricture producing type of CD (Schulte et al., 2001; Hume et al., 2006) and differences in allele frequencies and genotypes of the $-800 \mathrm{G} / \mathrm{A}$ polymorphism were reported between patients with UC and control subjects (Tamizifar et al., 2008). In our study, we could not find any statistically significant differences between three TGF- $\beta 1$ polymorphisms, namely $-800 \mathrm{G} / \mathrm{A}, 869 \mathrm{~T} / \mathrm{C}$ and $915 \mathrm{G} / \mathrm{C}$, and susceptibility to IBD. The only statistically significant difference detected was a higher number of -509 CT heterozygotes in the control group relative to IBD patients $(p=0.04)$. However, such a difference seems to be of minor importance due to their relatively weak statistical support and the difficult to explain advantage of heterozygosity over two kinds of homozygosity in susceptibility to the disease. Moreover, no statistically significant differences were found when testing all four polymorphisms in relation to the clinical parameters of IBD.

An obvious question is why our results differ from those published earlier. One clear difference between our study and those reported by others (Schulte et al., 2001; Hume et al., 2006; Tamizifar et al., 2008) is that we have investigated pediatric patients with IBD while those authors tested adult patients suffering from this disease. However, while the age of patients may influence the relationship between TGF- $\beta 1$ polymorphisms and susceptibility to and/or clinical parameters of IBD, it is worth mentioning that a lack of correlations between these items was indicated previously by some researchers who investigated adult IBD patients (Garcia-Gonzalez et al., 2000; Tamizifar et al., 2007). Thus, we speculate that other factors, apart from age, may be responsible for the discrepancy between results obtained by different authors. One factor is a population-specific genetic background, as it is worth noting that patients investigated by various authors came from as different geographical regions as The Netherlands (Garcia-Gonzalez et al., 2000), Germany (Schulte et al., 2001), Australia (Hume et al., 2006), Iran (Tamizifar et al., 2007, 2008), and Poland (this report). The second factor is a possible genetic coupling between $T G F-\beta 1$ locus and another locus, which is actually responsible for modulation of the disease susceptibility or clinical parameters; in such a case, the link between a particular TGF- $\beta 1$ polymorphism and IBD might be coincidental. It appears that the occurrence of such a possibility is often underestimated when testing

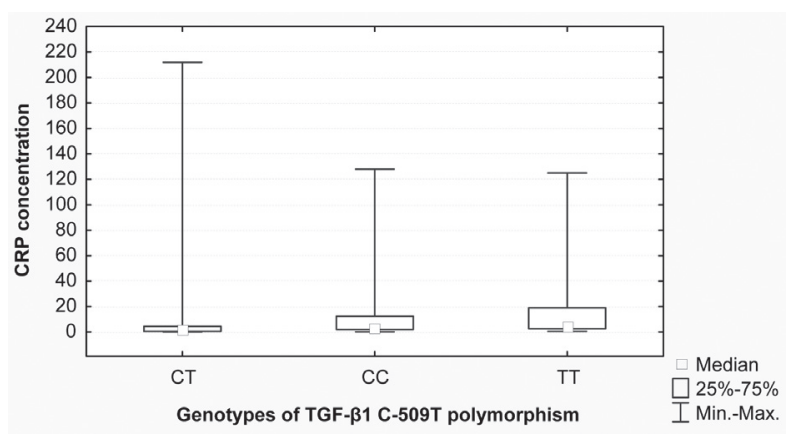

Figure 3. CRP concentration $(\mathrm{mg} / \mathrm{dl})$ in relation to genotypes of TGF- $\beta 1$ C-509T polymorphism in the study group. 
correlations between genetic polymorphisms and various diseases. Finally, one may assume that correlation between a single genetic polymorphism and a specific disease symptom or parameter can be influenced by so many other genetic factors that any definite conclusions must be postponed until the molecular mechanism of a putative genetic link is elucidated.

It is obvious that further studies, including those on larger and ethnically differentiated groups of patients, are necessary to solve the problem of different results of studies on correlations between TGF- $\beta 1$ polymorphisms and IBD. Moreover, further studies are also required to test whether correlations between the TT genotype at the -509 position of the TGF- $\beta 1$ locus and an increased platelet count in IBD pediatric patients, and between the -509CC genotype and an increased CRP level, described in this report, have any clinical importance. Nevertheless, in our opinion, no strong conclusions should be proposed until principles of molecular mechanisms of influence of any particular polymorphisms on certain biochemical or clinical effects are elucidated.

\section{Financial support}

Ministry of Science and Higher Education, Poland (project grant no. 2P05E 12527 ) and University of Gdansk (task grant no. DS/L140-4-0114-11).

\section{REFERENCES}

Bayat A, Watson JS, Stanley JK, Ferguson MW, Ollier WE (2002) Novel single nucleotide polymorphisms in the 3'-UTR of the TGFbetaRI and TGFbetaRIII genes. Eur I Immunogenet 29: 445-446.

Cambien F, Ricard S, Troesch A, Mallet C, Générénaz L, Evans A, Arveiler D, Luc G, Ruidavets JB, Poirier O (1996) Polymorphisms of the transforming growth factor-beta 1 gene in relation to myocardial infarction and blood pressure. The Etude Cas-Témoin de l'Infarctus du Myocarde (ECTIM) Study. Hypertension 28: 881-887.

Cantor MJ, Nickerson P, Bernstein CN (2005) The role of cytokine gene polymorphisms in determining disease susceptibility and phenotype in inflammatory bowel disease. Am J Gastroenterol 100: 1134 1142 .

Coll E, Cormand B, Campos B, González-Núñez D, Iñigo P, Botey A, Poch E (2004) Association of TGF-beta1 polymorphisms with chronic renal disease. J Nephrol 17: 794-799.

Cotton SA, Gbadegesin RA, Williams S, Brenchley PE, Webb NJ (2002) Role of TGF-beta1 in renal parenchymal scarring following childhood urinary tract infection. Kidney Int 61: 61-67.

Derynck R, Rhee L, Chen EY, Van Tilburg A (1987). Intron-exon structure of the human transforming growth factor- $\beta 1$ precursor gene. Nucleic Acids Res 15: 3187-3189.

Drumm ML, Konstan MW, Schluchter MD, Handler A, Pace R, Zou F, Zariwala M, Fargo D, Xu A, Dunn JM, Darrah RJ, Dorfman R, Sandford AJ, Corey M, Zielenski J, Durie P, Goddard K, Yankaskas JR, Wright FA, Knowles MR (2005) Gene Modifier Study Group. Genetic modifiers of lung disease in cystic fibrosis. $N$ Engl J Med 353: 1443-1453.

Fiocchi C (1998) Inflammatory bowel disease: etiology and pathogenesis. Gastroenterology 114: 182-205.

Garcia-Gonzalez MA, Crusius JBA, Strunk MHP, Bouma G, PerezCenteno CM, Pals G, Meuwissen SGM, Pena AS (2000). TGFB1 gene polymorphisms and inflamatory bowel disease. Immunogenetics 51: 869-872.

Gewaltig J, Mangasser-Stephan K, Gartung C, Biesterfeld S, Gressner AM (2002). Association of polymorphisms of the transforming growth factor-beta1 gene with the rate of progression of HCV-induced liver fibrosis. Clin Chim Acta 316: 83-94.

Grainger DJ, Heathcote K, Chiano M, Snieder H, Kemp PR, Metcalfe JC, Carter ND, Spector TD (1999). Genetic control of the circulating concentration of transforming growth factor type beta1. Hum Mol Genet 8: 93-97.

Hume GE, Fowler EV, Lincoln D, Eri R, Templeton D, Florin TH, Cavanaugh JA, Radford-Smith GL (2006). Angiotensinogen and transforming growth factor beta1: novel genes in the pathogenesis of Crohn's disease. J Med Genet 43: e51.

Hyams JS, Ferry GD, Mandel FS, Gryboski JD, Kibort PM, Kirschner BS, Griffiths AM, Katz AJ, Grand RJ, Boyle JT et al (1991). Development and validation of a pediatric Crohn's disease activity index. J Pediatr Gastroenterol Nutr 12: 439-447.

IBD Working Group of the European Society for Paediatric Gastroenterology, Hepatology and Nutrition (2005). Inflammatory bowel disease in children and adolescents: recommendations for diagnosis - the Porto criteria. J Pediatr Gastroenterol Nutr 41: 1-7.

Kim YJ, Lee HS, Im JP, Min BH, Kim HD, Jeong JB, Yoon JH, Kim CY, Kim MS, Kim JY, Jung JH, Kim LH, Park BL, Shin HD (2003). Association of transforming growth factor-beta1 gene polymorphisms with a hepatocellular carcinoma risk in patients with chronic hepatitis B virus infection. Exp Mol Med 35: 196-202.

Langdahl BL, Knudsen JY, Jensen HK, Gregersen N, Eriksen EF (1997) A sequence variation: 713-8delC in the transforming growth factor-beta 1 gene has higher prevalence in osteoporotic women than in normal women and is associated with very low bone mass in osteoporotic women and increased bone turnover in both osteoporotic and normal women. Bone 20: 289-294.

Lee-Chen GJ, Liu KP, Lai YC, Juang HS, Huang SY, Lin CY (2004) Significance of the tissue kallikrein promoter and transforming growth factor-beta1 polymorphisms with renal progression in children with vesicoureteral reflux. Kidney Int 65: 1467-1472.

Mak JC, Leung HC, Ho SP, Law BK, Ho AS, Lam WK, Ip MS, ChanYeung MM (2006). Analysis of TGF-beta(1) gene polymorphisms in Hong Kong Chinese patients with asthma. J Allergy Clin Immunol 17: 92-96.

Osterreicher CH, Datz C, Stickel F, Hellerbrand C, Penz M, Hofer H, Wrba F, Penner E, Schuppan D, Ferenci P (2005) TGF-beta1 codon 25 gene polymorphism is associated with cirrhosis in patients with hereditary hemochromatosis. Cytokine 1: 142-148.

Park BL, Han IK, Lee HS, Kim LH, Kim SJ, Shin HD (2003). Identification of novel variants in transforming growth factor-beta 1 (TGFB1) gene and association analysis with bone mineral density. Hum Mutat 22: 257-258.

Powrie F, Carlino J, Leach MW, Mauze S, Coffman RL (1996). A critical role for transforming growth factor-beta but not interleukin 4 in the suppression of $\mathrm{T}$ helper type 1-mediated colitis by CD45RB(low) CD4+ T cells. J Exp Med 183: 2669-2674.

Schulte C, Goebell H, Roher HD, Schulte KM (2001) C-509T polymorphism in the TGFB1 gene promoter: impact on Crohn's disease susceptibility and clinical parameters? Immunogenetics 53: 178-182.

Stanisławowski M, Wierzbicki PM, Gołąb A, Adrych K, Kartanowicz D, Wypych J, Godlewski J, Smoczyński M, Kmieć Z (2009) Decreased Toll-like receptor-5 (TLR-5) expression in the mucosa of ulcerative colitis patients. J Physiol Pharmacol 60 (Suppl 4): 71-75.

Suzuki S, Tanaka Y, Orito E, Sugauchi F, Hasegawa I, Sakurai M, Fujiwara K, Ohno T, Ueda R, Mizokami M (2003). Transforming growth factor-beta-1 genetic polymorphism in Japanese patients with chronic hepatitis C virus infection. J Gastroenterol Hepatol 18: 1139-1143.

Syrris P, Carter ND, Metcalfe JC, Kemp PR, Grainger DJ, Kaski JC, Crossman DC, Francis SE, Gunn J, Jeffery S, Heathcote K (1998) Transforming growth factor-beta1 gene polymorphisms and coronary artery disease. Clin Sci 95: 659-667.

Tamizifar B, Bagheri-Lankarni K, Naeemi S, Rismankar-Zadeh M, Taghavi A, Ghaderi A (2007) Polymorphism of the promoter region of C-509T of transforming growth factor-beta1 gene and ulcerative colitis. Arch Iranian Med 10: 171-175.

Tamizifar B, Lankarani KB, Naeimi S, Rismankar-Zadeh M, Taghavi A, Ghaderi A (2008) Promoter polymorphism of transforming growth factor- $\beta 1$ gene and ulcerative colitis. World J Gastroenterol 14: 243-247.

Truelove SC, Witts LJ (1954) Cortisone in ulcerative colitis; preliminary report on a therapeutic trial. $\mathrm{Br}$ Med J 2: 375-378.

Vidigal PG, Germer JJ, Zein NN (2002) Polymorphisms in the interleukin-10, tumor necrosis factor-alpha, and transforming growth factor-beta1 genes in chronic hepatitis $C$ patients treated with interferon and ribavirin. $J$ Hepatol 36: 271-277.

Wierzbicki PM, Adrych K, Kartanowicz D, Wypych J, Stanislawowski M, Zwolinska-Wcislo M, Celinski K, Skrodzka D, Godlewski J, Korybalski B, Smoczynski, M, Kmiec Z (2009) Overexpression of the fragile histidine triad (FHIT) gene in inflammatory bowel disease. $J$ Physiol Pharmacol 60 Suppl 4: 57-62.

Yang YH, Lai HJ, Kao CK, Lin YT, Chiang BL (2004) The association between transforming growth factor-beta gene promoter C-509T polymorphism and Chinese children with Henoch-Schönlein purpura. Pediatr Nephrol 19: 972-975. 